\title{
MEDICOLEGAL AND CLINICAL ASPECTS OF PERIPHERAL VASCULAR INJURIES: A RETROSPECTIVE STUDY
}

\author{
Abo Elyazied A. Fouad ${ }^{1,2}$, Ahmed Mousa ${ }^{3,4}$, Ossama M. Zakaria ${ }^{4,5}$, Hazem M. Zakaria ${ }^{6}$ \\ ${ }^{1}$ Department of Forensic Medicine and Clinical Toxicology, Faculty of Medicine, Tanta \\ University, Tanta, Egypt \\ ${ }^{2}$ Division of Forensic Medicine, Department of Biomedical Science, College of Medicine, King \\ Faisal University, Al-Ahsa, Saudi Arabia \\ ${ }^{3}$ Department of Vascular Surgery, Al-Hussain University Hospital, Faculty of Medicine for Males, \\ Al-Azhar University , Cairo, Egypt \\ ${ }^{4}$ Divisions of Vascular and Pediatric Surgery, Department of Surgery, College of Medicine, King \\ Faisal University Al-Ahsa, Saudi Arabia \\ 5 Division of Pediatric Surgery, Department of Surgery, Faculty of Medicine, Suez Canal \\ University, Ismailia, Egypt \\ ${ }^{6}$ Department of Surgery, King Fahad Hospital of Imam Bin Abdul Rahman Al-Faisal University, \\ Dammam, Saudi Arabia
}

\section{Corresponding author}

DR. Abo Elyazied A. Fouad, MD*

ORCID ID: 0000-0002-8743-1852

E-mail address: draboyazid@yahoo.com

Phone: +966580349754

Postal address: Division of Forensic Medicine- Biomedical Sciences Department, College of Medicine-King Faisal University, Al-Ahsa, Saudi Arabia.

Postal code: 3198

\section{ABSTRACT}

Background: Vascular trauma is one of the devastating types of injuries whether accidental or intentional. Despite this fact, there is an obvious deficiency in the educational sessions for vascular surgeons concerning the appropriate medicolegal dealing with such injuries. Aim: To report the experience of vascular limb trauma 
highlighting the medicolegal and clinical findings. Methods: A 5-years retrospective study with a follow up period of 1.5 years studying the data of peripheral vascular injuries at three specialized trauma centers with special emphasize on the cause, the type, and the outcome of this trauma in relation to sociodemographic factors. Obtained data were statistically analyzed using the SPSS computer program (version 23). Results: This study included 350 trauma patients (287 males and 63 females) who presented with peripheral vascular injuries. The patients' age ranged from $<8$ years to $>50$ years. There was a significant association between the age and the circumstances of trauma. The most encountered causative mechanisms were traffic accidents (45.7\%) and firearms (21.7\%). There was no significant association between outcome and age $(\mathrm{p}=0.114)$ or circumstances of trauma $(\mathrm{p}=0.208)$. There was a highly significant association between the outcome and the duration of hospital stay $(\mathrm{p}<0.001)$. Lower limb injuries were higher in frequency than upper limb injuries $(n=286$ and 123) respectively. Upper and lower limbs arterial injuries had a significantly higher frequency rate than the venous injuries. Ulnar artery and brachial vein injuries was the most frequently encountered upper limb arterial and venous trauma, while the femoral artery and the deep femoral vein were the most commonly affected lower limb vessels. Bone injuries were the most frequently accompanying injuries (44.6\% of total cases). Conclusion: As any sort of injury may possess medical and lawful perspectives, medicolegal investigations have to take the crown's position when studying trauma cases, going hand in hand with the clinical aspect.

Keywords: Peripheral vascular trauma; Medicolegal aspects; Traffic accidents

\section{INTRODUCTION}

Trauma is accused of $10 \%$ of all deaths worldwide, and the fifth leading cause of expressed disabilities (Puvanachandra et al., 2012). It remains the most important public health problem and the main cause of mortality and disability through the first four decennia of life (Nepal et al., 2015, Andreas et al., 2016). The implication of trauma varies from threatening life to destruction of mental and physical health as well as, the negative impacts on both frugal and social up growth (Gupta et al., 2015; Mahran et al., 2016).

The influence of undue mechanical forces on the body tissues may result in compression, traction, and torsion as well as shearing (Ding et al., 2016). Factors affecting the consequent damage implicate the type of the imposed mechanical force and the nature of the targeted tissues (Barekand Haque, 2013).

One of the important categories of any wound is its inflection's manner whether suicidal or accidental (Carla et al., 2017).

They are usually classified into; abrasions (grazes or scratches), contusions (bruises), lacerations (cuts or tears) and incised wounds (slashes or stabs) (Ding et al., 2016).

By 2020, injuries are anticipated to exceed communicable diseases on a 
secular standard as the prime reason of inability (Kubat et al., 2015; Rich and Walker, 2016).

Developing countries still have a defect in injury prevention programs. This may be caused by many factors such as; the imperfect information for studies, lack of accuracy in detecting trauma bearding and Nevertheless, in other areas such as Egypt and according to the World Health Organization (WHO) report, road-related injuries mortality accounts for $2.37 \%$ of the total death cases annually. The death rate is 14.46 per 100.000 of population. (Abdulla et al., 2015).

These injuries are one of the grave causes for morbidity and mortality. They are believed as the fifth leading cause of death and the main occasion for hospitalization for approximately onequarter of all in patients (Ghaleb et al., 2018).

Vascular trauma whether arterial, venous, and/or blood- rich organ injuries are among the life threating conditions. They may be due to blunt trauma leading to crushing or stretching to the blood vessel or a penetrating injury resulting in puncture, torning or severing of a blood vessel (Kubat et al., 2015; Rich and Walker, 2016).

Vascular trauma may cause clot formation or a life-threatening haemorrhage that interrupts the normal blood flow to the body organs and/or extremities. (Nepal et al., 2015; Raherinantenaina et al., 2016).

On the other hand, wall defects, complete or partial transections, as well as arterio-venous fistulae (AVF) may accompany penetrating trauma( Rich and Walker, 2016; Weale et al., 2018).

Arterial spasm may be caused by blunt or penetrating trauma to the extremities (Eachempati et al., 2002; Kubat et al., 2015).

A traumatic false aneurysm is formed when the surrounding tissues encapsulate The aim of this study was to retrospectively analyze the cases of limbs' vascular trauma in a period of 5 years with a follow up period of 1.5 years. It also aimed to describe the available medicolegal aspects beyond such injuries in those cases.

\section{PATIENTS AND METHODS}

This five years - retrospective study took place from January 2012 to December 2016 with a follow up period of 1.5 years. It included all patients presented with sustained extremities vascular injuries who were treated at three tertiary referral centres in the Eastern Province, Saudi Arabia. After obtaining the approval of the institute research board with regard to the ethical issues of the study, demographic and clinical data, as well as, laboratory and radiological findings were reported through each patient's file. Data was analyzed and the following relationships were studied:

A) Circumstances of the injuries in relation to age, sex of the studied patients and the origin of trauma.

B) Age and sex in relation to the time they asked medical advice as well as the period of hospital stay after the intervention. 
C) The frequencies of the injured vessels in relation to the type and site of injury.

D) Vascular injuries in relation to other accompanied lesions such as musculoskeletal injuries.

Diagnosis was based on the essence of history and both the hard and soft clinical signs of arterial injury (e.g. progressively increasing hematoma, pulsatile bleeding, impalpable distal pulses, the presence of thrill, and bruit) as described in (Table1), (Strong and Edwards 2002; Nazem etories. Pearson's Chi-square test was applied to examine the association between two variables. Fisher exact or FisherFreeman-Halton Exact tests were employed if the expected count was less than five in any cell. Significance was adopted at $p<0.05$ for interpretation of results of tests (William et al., 2015).

Table (1): Hard and soft signs of arterial injury (Strong and Edwards 2002;

Nazem et al., 2009).

\begin{tabular}{|l|l|}
\hline \multirow{4}{*}{$\begin{array}{l}\text { Hard } \\
\text { signs }\end{array}$} & $\begin{array}{l}\text { Active hemorrhage } \\
\text { Absent distal pulses or } \\
\text { ischemia }\end{array}$ \\
\cline { 2 - 2 } & $\begin{array}{l}\text { Expanding or pulsatile } \\
\text { hematoma }\end{array}$ \\
\cline { 2 - 2 } & Bruit or thrill \\
\hline \multirow{4}{*}{$\begin{array}{l}\text { Soft } \\
\text { signs }\end{array}$} & $\begin{array}{l}\text { Subjective reduced or unequal } \\
\text { pulses }\end{array}$ \\
\cline { 2 - 2 } & $\begin{array}{l}\text { Large non-pulsatile hematoma } \\
\text { high index of suspicion of } \\
\text { vascular injury }\end{array}$ \\
\cline { 2 - 2 } & Neural injury \\
\cline { 2 - 2 } & History of large hemorrhage on \\
\hline
\end{tabular}

\section{RESULTS}

In this study, 350 victims with limb injuries were included; out of which 63 (18\%) were women and $287(82 \%)$ were men. They were of different ages ranging from 5 years up to 65 years with the mean of $23.27 \pm 7.83$ years. The most encountered causative mechanisms were traffic accidents $(45.7 \%)$ and firearms $(21.7 \%)$. As illustrated in (Figure 1), the highest incidence of trauma was in age group 20-35 years (males $34.5 \%$, females $8.5 \%$ ) while the lowest incidence was encountered in age group $<8$ with a statistically significant results 


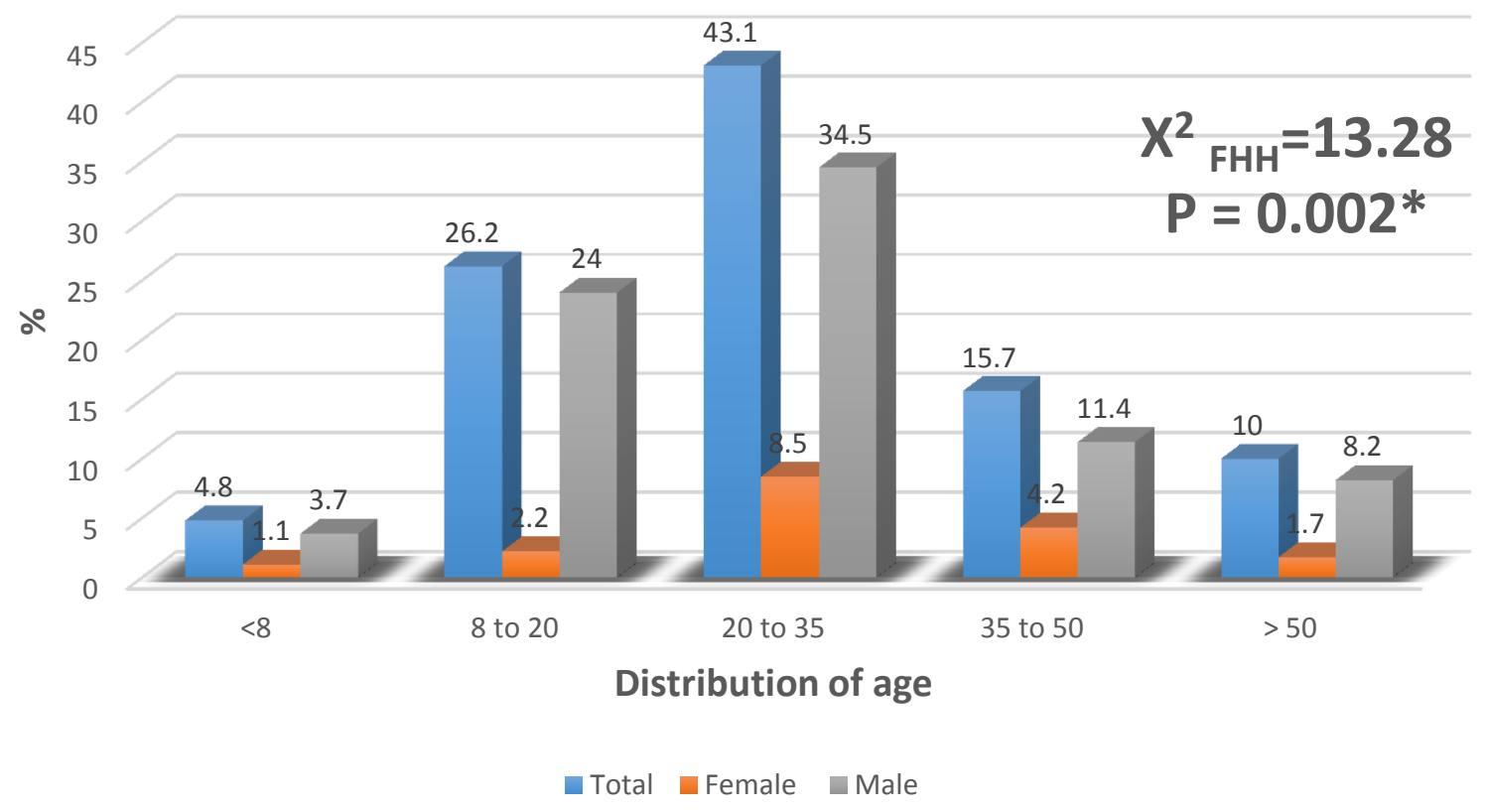

Figure (1): distribution of age in relation to sex, *significant at 0.01 .

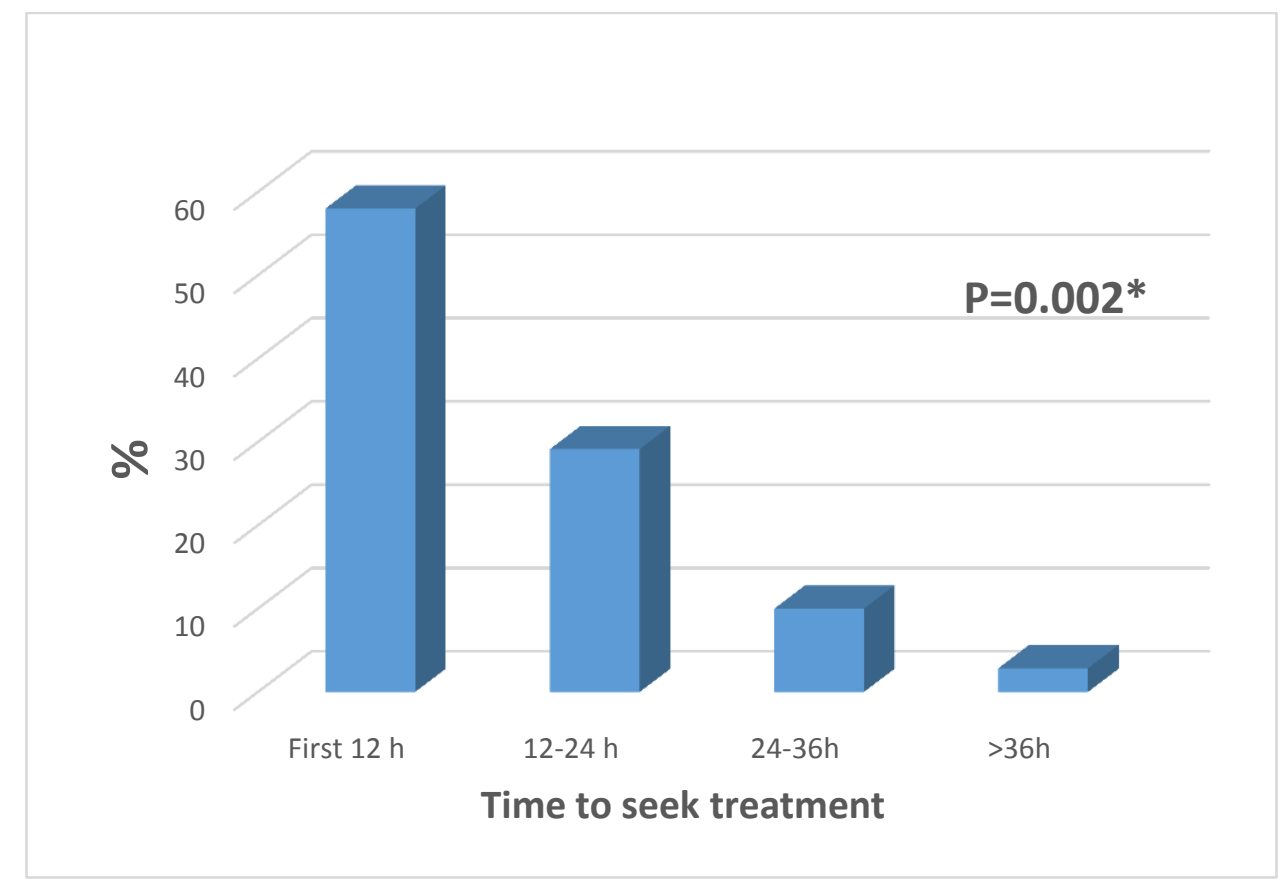

Figure (2): Time between trauma and seeking treatment in all patients, * significant at 0.01 . 
Table (2): Association between circumstances of trauma and sex, age, and causative instruments

\begin{tabular}{|c|c|c|c|c|c|c|c|c|c|c|c|}
\hline & \multicolumn{8}{|c|}{ Circumstances of trauma } & \multirow{2}{*}{\multicolumn{2}{|c|}{$\begin{array}{l}\text { Fisher-Freeman- } \\
\text { Halton test }\end{array}$}} \\
\hline & & \multicolumn{2}{|c|}{$\begin{array}{c}\text { Total } \\
(\mathbf{n}=\mathbf{3 5 0})\end{array}$} & \multicolumn{2}{|c|}{$\begin{array}{c}\text { Accidental } \\
(\mathbf{n}=70)\end{array}$} & \multicolumn{2}{|c|}{$\begin{array}{c}\text { Assault } \\
(\mathrm{n}=\mathbf{2 7 5})\end{array}$} & \multicolumn{2}{|c|}{$\begin{array}{c}\text { Self-inflicted } \\
(\mathbf{n}=5)\end{array}$} & & \\
\hline & & $\mathrm{n}$ & $\%$ & $\mathrm{n}$ & $\%$ & $\mathrm{n}$ & $\%$ & $\mathrm{n}$ & $\%$ & $\mathrm{X}^{2}$ & $\mathrm{p}$ \\
\hline \multirow{2}{*}{ Sex } & Female & 63 & $18.0 \%$ & 12 & $17.1 \%$ & 50 & $18.2 \%$ & 1 & $20.0 \%$ & \multirow{2}{*}{0.290} & \multirow{2}{*}{1.000} \\
\hline & Male & 287 & $82.0 \%$ & 58 & $82.9 \%$ & 225 & $81.8 \%$ & 4 & $80.0 \%$ & & \\
\hline \multirow{5}{*}{$\begin{array}{c}\text { Age } \\
\text { (Years) }\end{array}$} & $<8$ & 17 & $4.9 \%$ & 8 & $11.4 \%$ & 7 & $2.5 \%$ & 2 & $40.0 \%$ & \multirow{5}{*}{95.900} & \multirow{5}{*}{$<0.001 *$} \\
\hline & 8 to 20 & 92 & $26.3 \%$ & 10 & $14.3 \%$ & 80 & $29.1 \%$ & 2 & $40.0 \%$ & & \\
\hline & 20 to 35 & 151 & $43.1 \%$ & 11 & $15.7 \%$ & 140 & $50.9 \%$ & 0 & $0.0 \%$ & & \\
\hline & 35 to 50 & 55 & $15.7 \%$ & 15 & $21.4 \%$ & 40 & $14.5 \%$ & 0 & $0.0 \%$ & & \\
\hline & $>\mathbf{5 0}$ & 35 & $10.0 \%$ & 26 & $37.1 \%$ & 8 & $2.9 \%$ & 1 & $20.0 \%$ & & \\
\hline \multirow{5}{*}{ Causes } & Cutting/stabbing tools & 42 & $12.0 \%$ & 12 & $17.1 \%$ & 30 & $10.9 \%$ & 0 & $0.0 \%$ & \multirow{5}{*}{5.225} & \multirow{5}{*}{0.697} \\
\hline & Firearms & 76 & $21.7 \%$ & 15 & $21.4 \%$ & 60 & $21.8 \%$ & 1 & $20.0 \%$ & & \\
\hline & Industrial accidents & 53 & $15.1 \%$ & 8 & $11.4 \%$ & 45 & $16.4 \%$ & 0 & $0.0 \%$ & & \\
\hline & Traffic accident & 160 & $45.7 \%$ & 33 & $47.1 \%$ & 123 & $44.7 \%$ & 4 & $80.0 \%$ & & \\
\hline & Other blunt tools & 19 & $5.4 \%$ & 2 & $2.9 \%$ & 17 & $6.2 \%$ & 0 & $0.0 \%$ & & \\
\hline
\end{tabular}

n: number; ${ }^{*}$ significant at $\mathrm{p}<0.05$.

For $(\mathrm{n}=75,21.43 \%)$ of cases. As shown in (Table 2), there was no significant association between the circumstances of trauma and sex ( $p=$ $1.000)$, or the causative mechanism ( $\mathrm{p}=$ 0.697). However, there was a highly significant association between the age and the circumstances of trauma. The assaulted cases aged between 20-35 years approaching higher percentage $(50.9 \%)$ versus $(15.7 \%$ and $0 \%)$ for accidental and self-inflicted respectively. Lower limb injuries were higher in frequency than upper limb injuries $(n=286$ and 123) respectively. As many victims had multiple injuries, the sum of injuries was far higher than the total number of victims. The total number of injured vessels in both upper and lower limbs in the studied victims was 409 in the 350 cases. Moreover, lower extremity vascular trauma accounted for a whether in the upper or in the lower limb (Table
3). As demonstrated in (Table 3), upper limb arterial injuries had a significantly higher frequency rate $(n=107,26.2 \%$ of all vascular injuries) than the venous injuries $(\mathrm{n}=16,3.9 \%, \mathrm{p}<0.001)$. Ulnar artery injury was the most frequently encountered upper limb arterial trauma (n $=33,8.1 \%$ ) followed by the brachial injury ( $n=32,7.8 \%$ ), (Figure 3 ) and the radial injury $(n=29,7.1 \%)$. On the other hand, brachial vein injury was the most common venous injury affecting the upper limb $(n=10,2.4 \%)$, followed by the axillary vein $(\mathrm{n}=3,0.7 \%)$. In continuity with (Table 3), lower limb arterial trauma showed a significantly high frequency rate $(\mathrm{n}=200,48.9 \%)$ than the venous injuries $(n=86,21 \%$, $\mathrm{p}<0.001)$. The femoral artery was the most commonly affected 
Table (3): The injured vessels in the upper and lower limbs

\begin{tabular}{|c|c|c|c|}
\hline Site of injury & Injured vessels & $\mathbf{n}$ & $\begin{array}{c}\% \text { of total vessel } \\
\text { injuries }\end{array}$ \\
\hline $\begin{array}{l}\text { Arteries of upper limb } \\
(\mathrm{n}=\mathbf{1 0 7}, \mathbf{2 6 . 2 \%} \text { of all injured vessels })\end{array}$ & $\begin{array}{c}\text { Axillary } \\
\text { Brachial } \\
\text { Radial } \\
\text { Ulnar } \\
\text { Superior ulnar collateral }\end{array}$ & $\begin{array}{c}12 \\
32 \\
29 \\
33 \\
1\end{array}$ & $\begin{array}{l}2.9 \\
7.8 \\
7.1 \\
8.1 \\
0.2\end{array}$ \\
\hline $\begin{array}{l}\text { Veins of upper limb } \\
(n=16,3.9 \% \text { of all injured vessels })\end{array}$ & $\begin{array}{c}\text { Axillary } \\
\text { Brachial } \\
\text { Radial } \\
\text { Ulnar } \\
\text { Superior ulnar collateral }\end{array}$ & $\begin{array}{c}3 \\
10 \\
1 \\
1 \\
1\end{array}$ & $\begin{array}{l}0.7 \\
2.4 \\
0.2 \\
0.2 \\
0.2\end{array}$ \\
\hline $\begin{array}{l}\text { Arteries of lower limb } \\
(n=200 ; 48.9 \% \text { of all injured vessels })\end{array}$ & $\begin{array}{c}\text { Deep femoral } \\
\text { Femoral } \\
\text { Popliteal } \\
\text { Anterior tibial } \\
\text { Posterior tibial } \\
\text { Fibular } \\
\text { Circumflex femoral } \\
\text { Dorsal artery of the foot }\end{array}$ & $\begin{array}{c}48 \\
65 \\
47 \\
15 \\
22 \\
1 \\
1 \\
1\end{array}$ & $\begin{array}{c}11.7 \\
15.9 \\
11.5 \\
3.7 \\
5.4 \\
0.2 \\
0.2 \\
0.2\end{array}$ \\
\hline $\begin{array}{l}\text { Veins of lower limb } \\
(n=86,21.0 \% \text { of all injured vessels })\end{array}$ & $\begin{array}{c}\text { Deep femoral } \\
\text { Femoral } \\
\text { Popliteal } \\
\text { Greater saphenous } \\
\text { Lesser saphenous } \\
\text { Accessory saphenous } \\
\text { Posterior tibial }\end{array}$ & $\begin{array}{c}33 \\
26 \\
23 \\
1 \\
1 \\
1 \\
1\end{array}$ & $\begin{array}{l}8.1 \\
6.4 \\
5.6 \\
0.2 \\
0.2 \\
0.2 \\
0.2\end{array}$ \\
\hline $\begin{array}{l}\text { Pearson's Chi square test } \\
\text { (limb \& vessels) }\end{array}$ & $\begin{array}{l}X^{2} \\
p\end{array}$ & $\begin{array}{l}13.375 \\
<0.001 *\end{array}$ & \\
\hline $\begin{array}{l}\text { Chi square goodness of fit test } \\
\text { (arteries \& veins) }\end{array}$ & $\begin{array}{c}X^{2} \\
p\end{array}$ & $\begin{array}{l}10.087 \\
<0.001^{*}\end{array}$ & \\
\hline $\begin{array}{l}\text { Chi square goodness of fit test } \\
\text { (upper \& lower limbs) }\end{array}$ & $\begin{array}{l}X^{2} \\
p\end{array}$ & $\begin{array}{c}10.112 \\
<0.001^{*}\end{array}$ & \\
\hline $\begin{array}{l}\text { Chi square goodness of fit test } \\
\text { (arteries \& veins in upper limb) }\end{array}$ & $\begin{array}{c}X^{2} \\
p\end{array}$ & $\begin{array}{c}8.115 \\
<0.001 *\end{array}$ & \\
\hline $\begin{array}{l}\text { Chi square goodness of fit test } \\
\text { (arteries \& veins in lower limb) }\end{array}$ & $\mathrm{X}^{2}$ & $\begin{array}{c}6.682 \\
<0.001 *\end{array}$ & \\
\hline
\end{tabular}

$\mathrm{n}$ : number; $*$ significant at $\mathrm{p}<0.05$.

Furthermore, the most frequently affected lower limb veins were the deep femoral $(n=33.8 .1 \%)$ followed by the femoral $(n=26,6.4 \%)$, and the popliteal vein $(n=23,5.6 \%)$. Bone injuries ntly encountered ( $44.6 \%$ of total cases), followed by nerve injuries $(32 \%)$. In addition, concomitant nerve and bone injuries were reported in (14.9\%) while an isolated blood vessel 


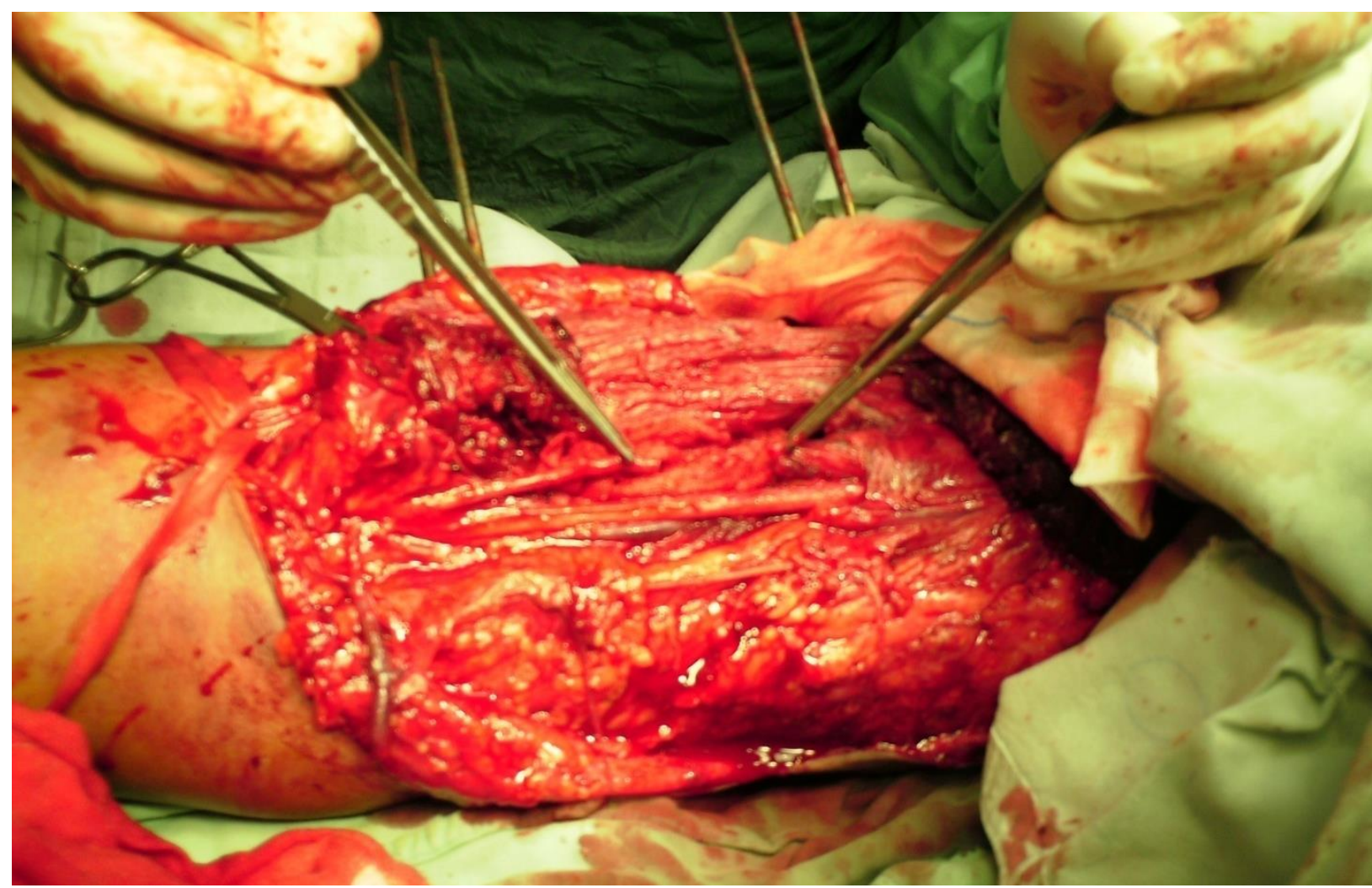

Figure (3): injury of the brachial artery.

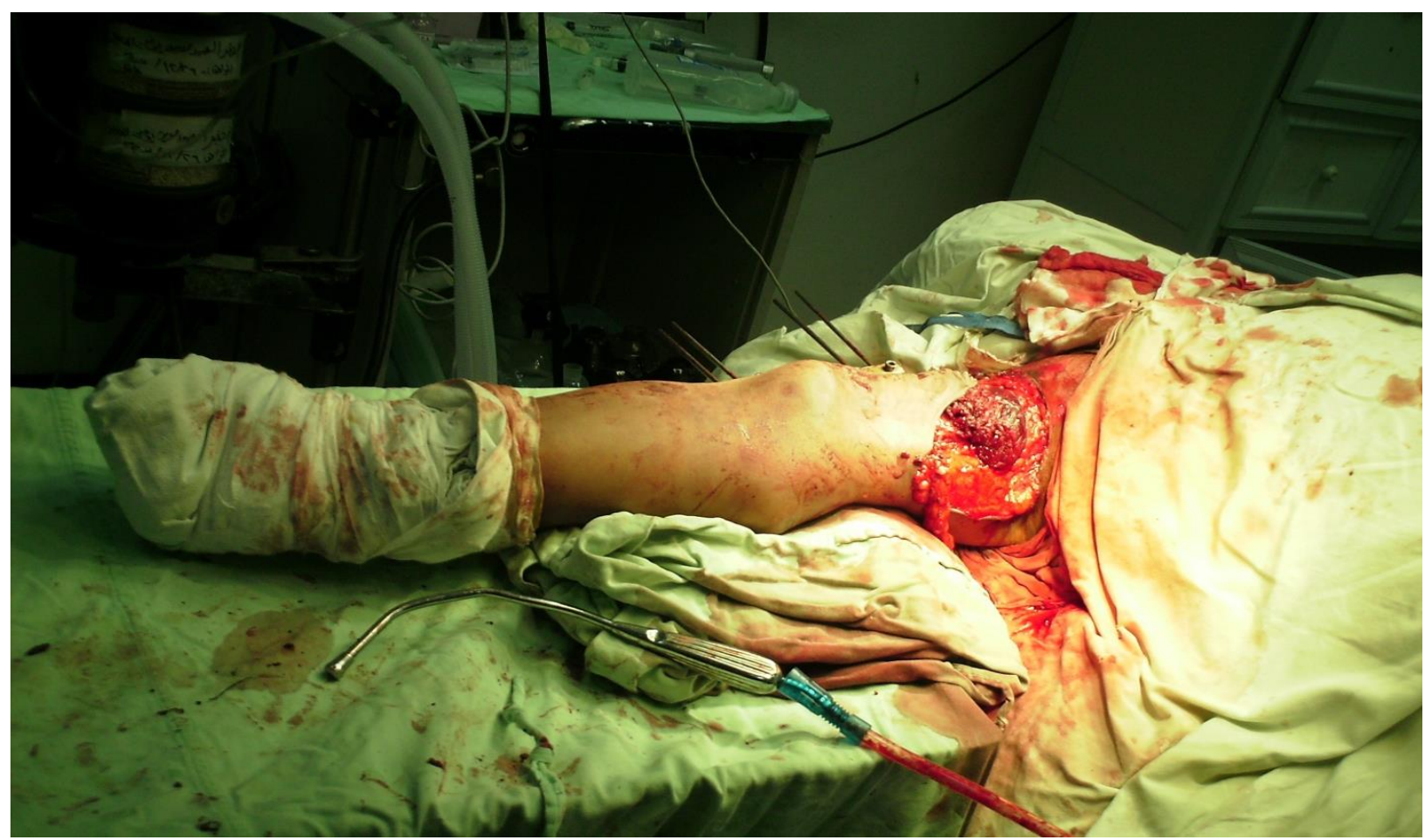

Figure (4): Brachial artery injury associated with soft tissue and comminuted bone injury with external fixator. 
Table (4): Association between the affected limb and the injuries

\begin{tabular}{|c|c|c|c|c|c|c|c|c|}
\hline & \multicolumn{6}{|c|}{ Site of injuries } & \multirow{2}{*}{\multicolumn{2}{|c|}{$\begin{array}{c}\text { Pearson's Chi } \\
\text { square test }\end{array}$}} \\
\hline & \multicolumn{2}{|c|}{ Total $(n=350)$} & \multicolumn{2}{|c|}{ Upper $\operatorname{limb}(n=123)$} & \multicolumn{2}{|c|}{ Lower $\operatorname{limb}(n=286)$} & & \\
\hline & $\mathrm{n}$ & $\%$ & $\mathrm{n}$ & $\%$ & $\mathrm{n}$ & $\%$ & $X^{2}$ & $\mathrm{p}$ \\
\hline Isolated vessel injuries & 25 & $7.1 \%$ & 10 & $8.1 \%$ & 15 & $6.6 \%$ & 0.279 & 0.598 \\
\hline Accompar & & & & & & & & \\
\hline Bone & 156 & $44.6 \%$ & 41 & $33.3 \%$ & 115 & $50.7 \%$ & 9.695 & $0.002 *$ \\
\hline Nerve & 112 & $32.0 \%$ & 37 & $30.1 \%$ & 75 & $33.0 \%$ & 0.321 & 0.571 \\
\hline Both bone and nerve & 52 & $14.9 \%$ & 16 & $13.0 \%$ & 36 & $15.9 \%$ & 0.513 & 0.474 \\
\hline Others & 64 & $18.3 \%$ & 19 & $15.4 \%$ & 45 & $19.8 \%$ & 1.023 & 0.312 \\
\hline
\end{tabular}

$\mathrm{n}$ : number; $*$ significant at $\mathrm{p}<0.05$.

(14.9\%) while an isolated blood vessel injury was reported in (7.1\%). There was no significant association between the injured limb and the type of the accompanying trauma except in bone fractures that showed a significantly higher rate in lower limb versus those in the upper limb (i.e. $50.7 \%$ versus $33.3 \%$ in upper limb) $\mathrm{p}=0.002$. These results are shown in (Table 4). The outcome of studied victims is demonstrated in (Table 5), most victims suffered complications (n $=178,50.85 \%), 110$ cases improved and major surgical interventions were performed in 50 out of them via primary
Furthermore, 46 cases had impaired limb functions, 10 cases lost extremities, and 6 cases died, with a statistically significant difference $(p<0.001)$. There was no significant association between outcome and age $(\mathrm{p}=0.114)$ or circumstances of trauma $(p=0.208)$. There was a highly significant association between the outcome and the duration of hospital stay ( $\mathrm{p}<0.001)$; as significantly higher percentages of improved cases had a hospital stay less than 14 days. Moreover, complicated cases had higher frequencies that stayed 14-21

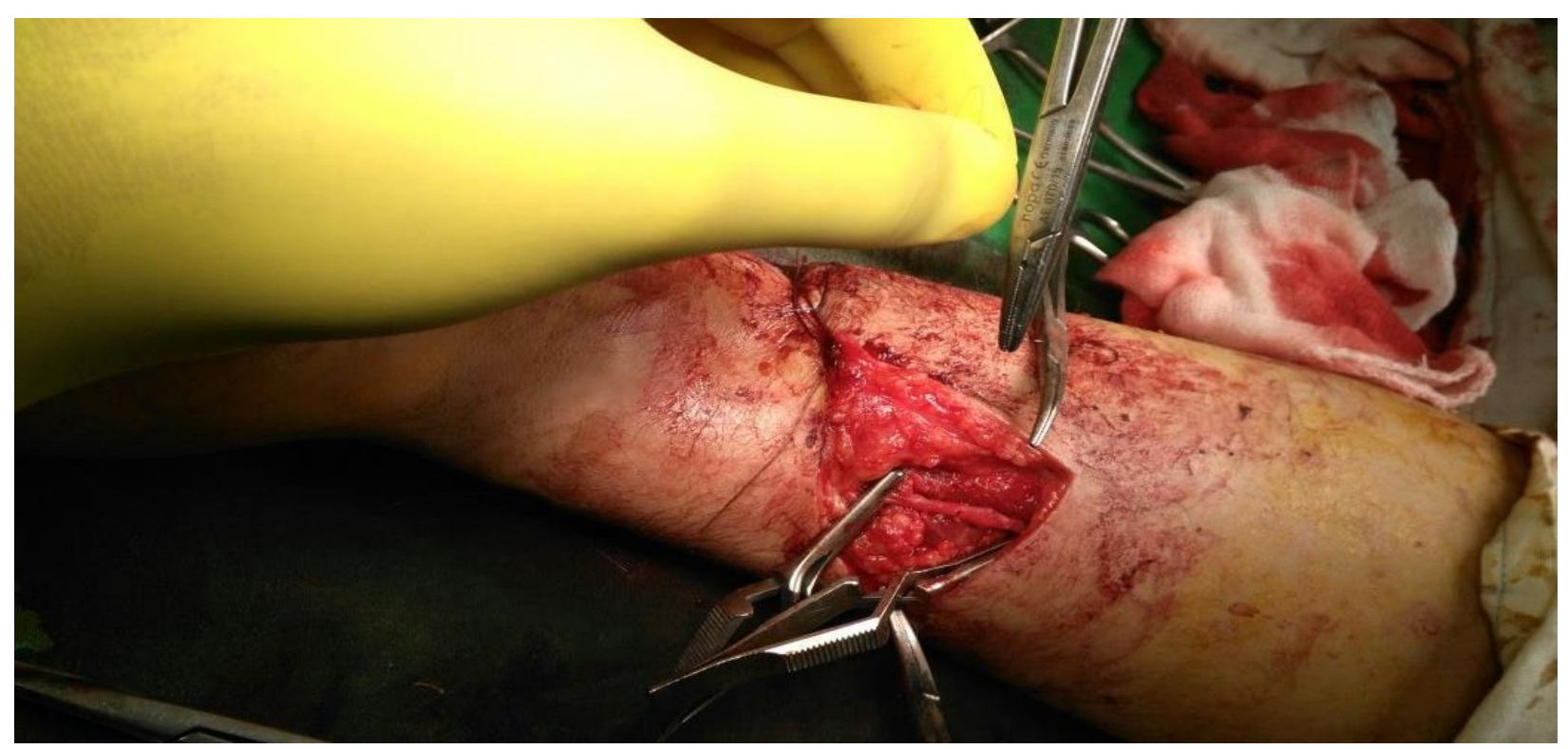

Figure (5): Primary repair with end-to-end vascular anastomosis of the radial artery 
Table (5): Association between the outcome of the studied victims and each of age, circumstances of trauma and hospital stay.

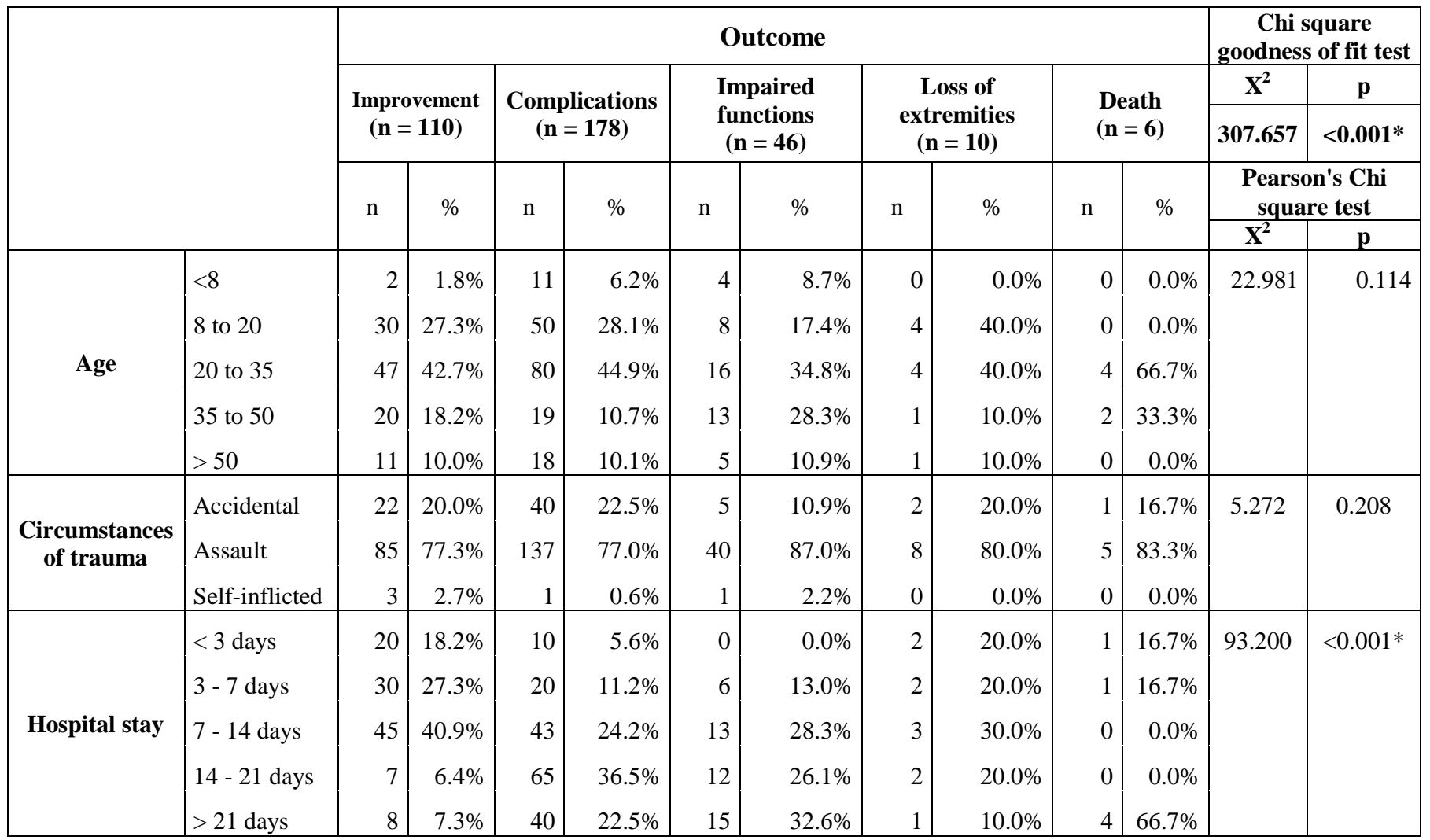

$\mathrm{n}$ : number; $*$ significant at $\mathrm{p}<0.05$.

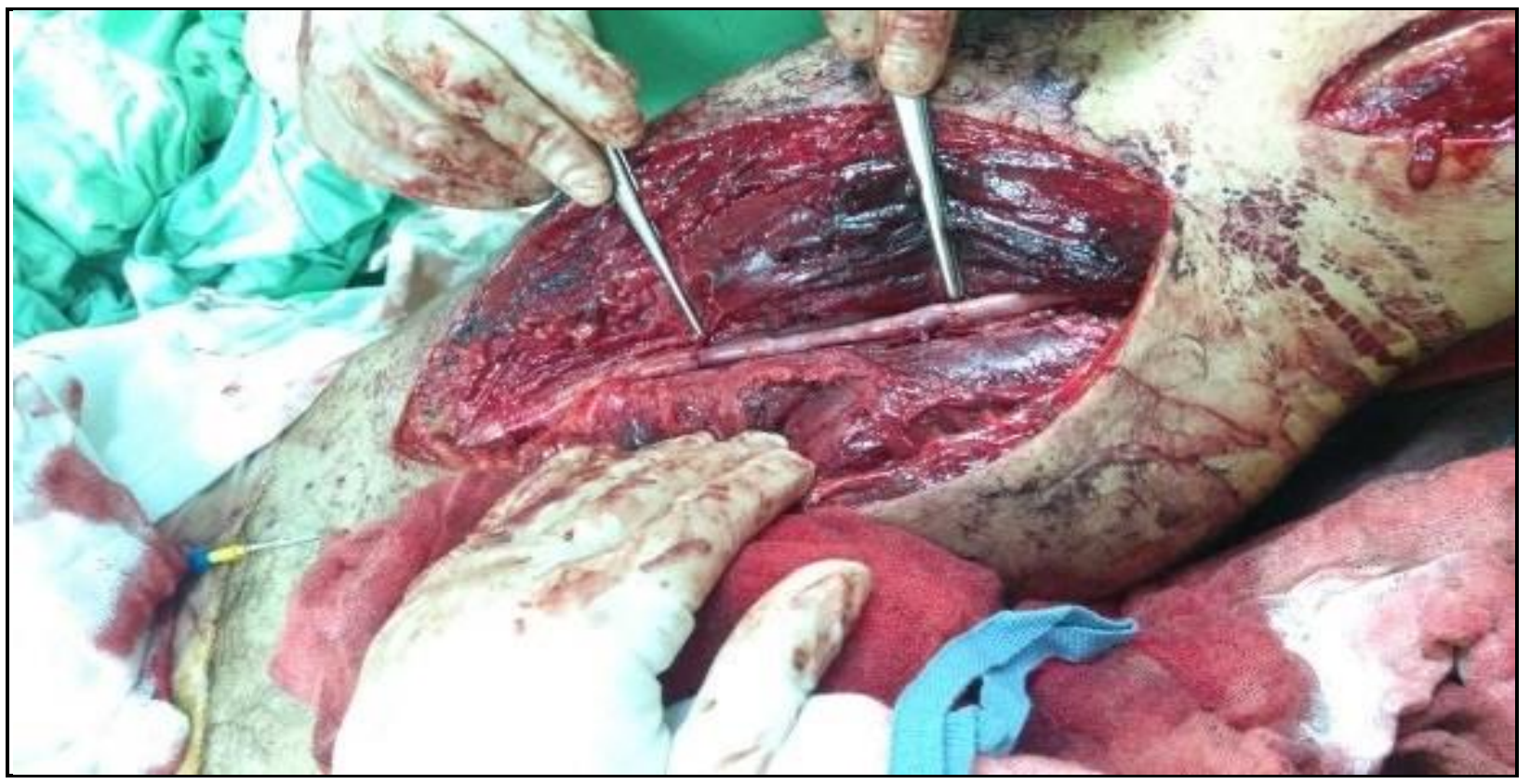

Figure (6): Femoral injury with interposition reversed saphenous vein graft 


\section{DISCUSSION}

Extremity vascular injuries pose a challenge to most surgeons. It is considered to be a major cause of morbidity and mortality in the developing countries. They are usually due to street offenses, imperfect roads planning, firearms, and other weapons correlated

trauma (Khan et al., 2015; Joshi, 2016) as well as self-inflection (Izawa et al., 2016).

According to the tort classical deterrence theory, the probability of litigation enforces the health care providers to be more cautious in their practice based on the well established standards of patients care, thereby, enhancing patient outcomes (Demetriades, 2011; Minami et al., 2014).

Most of this study population was males $(82 \%)$. This can be supported by previously published reports in which number of males is higher than females by variable percentage (Klinkner et al., 2007; Sciarretta et al., 2014; Allen et al., 2015; Gurien et al., 2017; Kayssi et al., 2018). The current work

at different ages ranging from 5 years up to 65 years. The most commonly affected age group was 20-35 years coinciding with data in the literature (Joshi, 2016). This might be attributed to the finding that this age category may be commonly exposed to high-risk events as it is considered the most productive age (Manakuru et al., 2005).

In our existing results, traffic accidents were reported as the most common mechanism of vascular trauma
$(45.7 \%)$ leading to either isolated vascular injuries or accompanying limb musculoskeletal fracture. Comparable data was notified in the literature with a variable degree (De Feyter 2003; Asirdizer et al., 2004: Milas et al., 2004; Linton et al., 2008; Adams 2014; Ziffra e $t$ al., 2018).

On the other hand, (Ekimand Tuncer, 2009) had reported penetrating trauma as the main causative mechanism in their study on 49 patients with brachial artery injuries. The results of the current work revealed no signif- icant association between the circumstances of trauma and sex or the causative mechanism. This may be attributed to the new development of the Saudi society where women are offered more freedom to share in the professional work life as a as well as the recent permission of car driving. One the other hand, (Mostafa et al., 2002) concluded that gender-specific trauma's frequencies, circumstances, and outcome in favour of males. In this work, most injuries occurred due to assault in 275 patients $(78.57 \%)$, followed by accidental in $(20 \%)$, and self-inflicted in $(1.43 \%)$. This data is contradicting to previously published reports that showed the prevalence of assault injuries to be 63\% in Australian (Taylor and Cameron 1998), and $35 \%$ in Indian populations (Swarnkar et al., 2016) respectively.

However, self-inflicted injuries were observed in the younger age group (i.e. $<20$ years) with a higher incidence rate. This result coincides with that reported in an American study (Bukur et al., 2011; Minami et al., 2014) and with study from Canada (Kayssi et al., 2018). 
The highly significant association between the outcome and the duration of hospital stay proved in this study was in agreement with that reported in other work investigating the ordinarily applied measurement for quality of care inside the hospitals (Lingsma et al., 2018).

The most commonly encountered lesion in the current study was lower limb trauma (70\%) with an injury to the superficial femoral artery coinciding with a previously published report (Bukur et al., 2011; Balestrine et al., 2014; Leow et al., 2016).

Arterial injuries showed a significantly increased rate compared to those presented with the venous injury. Both upper and lower extremity arterial injuries accounted for $(26.2 \%$ and $48.9 \%)$, respectively. This $\mathrm{m}$ ay be compared to those presented with venous injuries as it accounted for $(3.9 \%$ and $21 \%$ ) in the upper and lower limbs, respectively. Previous studies reported an increased incidence of lower extremity more than upper extremity vascular injuries that consistent with the report in this literature (Harris and Hordines, 2003, Fowler et al., 2009).

The second most commonly encountered pathology following vascular injury in patients with multiple injuries was the bony fracture $(44.6 \%)$. This result is approximately similar to a reported percentage of $37 \%$ in the literature (Manakuru et al., 2005).

The complications of traumatic extremity injuries were observed in most of our treated victims $50.85 \%(\mathrm{n}=178)$, while 46 cases (13.4\%) had impaired limb function and disability. This functional disability was coinciding with that reported in others literature (Franz etal., 2009; and Jaipuria et al., 2014). It may raise an important issue as regards the legal compensations and the quality of life.

\section{CONCLUSION}

Traffic accidents are the most accused reason for vascular limb injuries followed by gunshot either assault or self-inflicted. The current work had investigate numerous points of forensic interest in relation to vascular trauma but because it was conducted in a retrospective manner, the medicolegal data obtained from the patients' files are fewer if compared with those acquired from autopsy or recently injured cases. This might reflect the defects in forensic dealing with all cases of trauma and hence throw light on the importance of the proper forensic documentation with such injuries. This appropriate documentation might be of great significance for both patients and surgeons especially in cases liable to develop legal and/medicolegal consequences.

\section{RECOMMENDATION}

Conduction of adequate educational sessions for vascular surgeons concerning the appropr- iate medicolegal aspects dealing with vascular injuries. Raising public awareness about the implication of first aid measures for trauma management. Thoroughly employing road safety and transportation tools. Establishment of decisive international measures to combat all forms of terrorism. Proper implementation of safety and security measures in all worksites. A strict surveillance along the utilizing of weapons amongst civilians 
and increase lawful punishment for assaulters of the offense for trauma or killing by firearms or other types of weapons.

\section{ACKNOWLEDGMENT}

N/A

\section{REFERENCES}

Abdullah A., Mohammed H., and Mohammed A., (2015): Blunt traumatic subclavian vein pseudoaneurysm. J Vasc Surg Cases Rep, 1:214-6.

Abdulla N.M., EL Hakim S.A., Wahdan A.W., and EL-Refaeye M.A., (2016): Analysis of accidental cost in Egypt using the Willingnessto-pay method. International Journal of Traffic and Transport Engineering, 5(1):10-18.

Al-Naami M.Y., Maria A. Arafah, and Al-Ibrahim F.S., (2010): Trauma care systems in Saudi Arabia: an agenda for action. Ann Saudi Med, 30:50-8.

Andreas F.M., George N.P., Zinon T.K., Panayiotis K., Panayiotis D.M., et al., (2016): Vascular Injury in Orthopedic Trauma. Orthopedics, 39:249-59.

Alghnam S., Alkelya M., Al-Bedah K. and Al-Enazi S., (2014): Burden of traumatic injuries in Saudi Arabia: lessons from a major trauma registry in Riyadh, Saudi Arabia. Ann Saudi Med, 34:291-96.

Allen C.J., Straker R.J., Tashiro J., Teisch L.F., Meizoso J.P., et al., (2015): Pediatric vascular injury: experience of a level 1 trauma center. J Surg Res, 196:1-7.

Alshahri S.S., Cripps R.A., Lee B.B., and Al-Jadid M.S., (2012): Traumatic spinal cord injury in Saudi Arabia: an epidemiological estimate from Riyadh. Spinal Cord, 50:882-4.

Asirdizer M., Yavuz M.S., Buken E., Daglar S., and Uzun I., (2004): Medicolegal evaluation of vascular injuries of limbs in Turkey. J Clin Foresnic Med, 11(2):59-64.

Barek A., and Haque S.M., (2013): Medicolegal Aspects of Hurt, Injury and Wound. AKMMC J, 4:37-41.

Bukur M., Inaba K., Barmparas G., DuBose J.J., Lam L., et al., (2011): Self-inflicted penetrating injuries at a Level I Trauma Center. Injury, 42:474-7.

Carla L.C., Fátima H.S., Thayane D.S., Isaura S.B., Donizete V.D., et al., (2017): Knowledge and practices in care focused on individuals with wounds. Esc Anna Nery, 21:e20170036.

DeFeyter P.J., (2003): Percutaneous treatment of saphenous vein by-pass graft obstructions: a continuing obstinate problem. Circulation, 107:2284-6.

Demetriades D., (2011): Self-inflicted penetrating injuries at a Level I Trauma Center. Injury, 42:474-7.

Ding S., Lin F., and Gillespie B.M., (2016): Surgical wound assessment and documentation of nurses: an integrative review. J Wound Care, 25:232. 
Eachempati S.R., Robb T., Ivatury R.R., Hydo L.J., and Barie P.S., (2002): Factors associated with mortality in patients with penetrating abdominal vascular trauma. J Surg Res, 108:222-6.

Ekim H., and Tuncer M., (2009): Management of traumatic brachial ar tery injuries: a report on 49 patients. Ann Saudi Med, 29:105-9.

Estrera A.L., Sandhu H.K. and Leake S.S., (2015): Early and late outcomes of acute type A aortic dissection with intra- mural hematoma. J Thorac Cardiovasc Surg, 149:137-42.

Fowler J., Macintyre N., Rehman S., Gaughan J.P., and Leslie S., (2009): The importance of surgical sequence in the treatment of lower extremity injuries with concomitant vascular injury: A metaanalysis. Injury 40:72-6.

Franz R.W., Goodwin R.B., Hartman J.F., and Wright M.L., (2009): Management of upper extremity arterial injuries at an urban level I trauma center. Ann Vasc Surg, 23:816.

Ghaleb S.S., Hassan D.A., Shehab A.M., and Abd El-Ghafar S.M., (2018): Medico-legal aspects of disabilities due to orthopedic injuries and compensations in Egypt. J Forensic Leg Med, 58:43-40.

\section{Gupta S., Wong E.G., Nepal} S., Shrestha S., Kushner A.L., et al., (2015): Injury prevalence and causality in developing nations: Results from a countrywide population-based survey in Nepal. Surgery, 157:843-9.
Gurien L.A., Maxson R.T., Dassinger M.S., Mehl S.C., Saylors M.E, et al., (2017): Pediatric vascular injuries: Are we preparing trainees appropriately to meet our needs? The Am J of Surg, 214:336-40.

Haider A.H., Hashmi Z.G., Zafar S.N., Castillo R., Haut E.R., et al., (2014): Developing best practices to study trauma outcomes in large databases: An evidence-based approach to determine the best mortality risk adjustment model. J Trauma Acute Care Surg, 76:1061-9.

Harris L.M. and Hordines J. (2003): Major vascular injuries in the pediatric population. Ann VascSurg, 17:266-9.

Izawa Y., Suzukawa M., and Lefor A.K., (2016): Self-inflicted injuries are an important cause of penetrating traumatic injuries in Japan Acute Medicine \& Surgery, 3:305-9.

Jaipuria J., Saqar S., Singhal M., Gupta A., Kumar S., et al., (2014): Paediatric extremity vascular injuries - Experience from a large urban trauma centre in India. Injury, 45:176-82.

Joshi S.S. (2016): Peripheral Arterial Injuries: an Indian Experience. Indian J Surg, 78:187-91.

Khan F.H., Yousuf K.M., and Bagwani A.R., (2015): Vascular injuries of the extremities are major challenge in a third world country. J Trauma Manag Outcomes, 30:9:5.

Kayssi A., Metisa M., Langer J.C., Roche-Nagle G., Zani A., et al., (2018): The Spectrum and 
management of noniatrogenic vascular trauma in the pediatric population. J PediatrSurg, 53:771-4.

Klinkner D.B., Arca M.J., Lewis B.D., Oldhman K.T. and Sato T.T., (2007): Pediatric vascular injuries: patterns of injury, morbidity, and mortality. J Pediatr Surg, 42:178-83.

Kubat B.B., Buiskool M.M., and van Suylen R.J., (2015): Traumatic vertebral artery injury: proposal for classification of the severity of trauma and likelihood of fatal outcome. Int J Legal Med, 129:1418.

Leow J.J., Lingam P., lim V.W., Go K.T, Chiu M.T., et al., (2016): A review of stab wound injuries at a tertiary trauma centre in Singapore: are self-inflicted ones less severe? Singapore Med J, 57:13-7.

\section{Lingsma H.F., Bottle A., Middleton S.,} Kievit J., Ewout W. et al., (2018): Evaluation of hospitals outcomes: the relation between length of stay, readmission, and mortality in a large international administrative database. BMC Health Services Research, 18:116.

Linton J., Davies J., HomerVanniasinkam S., and McPherson S., (2008): Adolescent External Iliac Artery Trauma: Recurrent Aneurysmal Dilatation of an Iliofemoral Saphenous Vein Graft Treated by Stent-Gr- afting. Cardiovasc Intervent Radiol, 31(5):1018-22.

Mahran D.G., Farouk O., Qayed M.H., and Berraud A., (2016): Pattern and Trend of Injuries Among Trauma
Unit Attendants in Upper Egypt. Traum Mon, 20;21(2):e20967.

Manakuru S.R., Behera A., Jindal R., Doley R., and Venkatesan R., (2005): Extremity vascular trauma in civilian population: a seven-year review from North India. Injury, 36:400-6.

Milas Z.L., Dodson T.F., and Ricketts R.R., (2004): Pediatric blunt trauma resulting in major arterial injuries. Am Surg, 70:443-7.

Mostafa G., Huynh T., Sing R.F., Miles W.S., Norton H.J., et al., (2002): Gender-related outcomes in trauma. J Trauma, 53(3):430-434.

Minami C.A., Chung J.W., Holl J.L. and Bilimoria K.Y., (2014): Impact of medical malpractice environment on surgical quality and outcomes. J Am CollSurg, 218:271-8.

Nepal S., Gupta S., Wong E.G., Gurung S., Swaroop M., et al., (2015): Burden of road traffic injuries in Nepal: results of a countrywide population-based survey. Lancet, 27:385.

Nazem M., Beigi A.A., Sadeghi A.M., and Masoudpour H., (2009): Non iatrogenic paediatric vascular trauma of the extremities and neck. Afr J Paediatr Surg, 6:35-39.

Puvanachandra P., Hoe C., Elsayed H.F., Saad R., al-gasseer N., et al., (2012): Road Traffic Injuries and Data Systems in Egypt: Addressing the Challenge. Traffic Injury Prevention, 13(S1):44-56. 
Raherinantenaina F., Rajaonanahary T.M.A., and Rakoto Ratsimba H.N., (2016): Management of traumatic arterial pseudoaneurysms as a result of limb trauma. Formosan Journal of Surgery, 49:89-100.

Sciarretta J.D., Macedo F.I., Chung E.L., Otero C.A., Pizano L.R., et al., (2014): Management of lower extremity vascular injuries in pediatric trauma patients: A single level I trauma center experience. J Trauma Acute Care Surg, 76(6):1386-9.

Strong D.P. and Edwards A.T., (2002): Vascular Trauma. Trauma, 4:39-63.

Swarnkar M., Pal G., and Lilhare S., (2016): Assault and self-harm injuries: pattern, severity and etiology of injuries in victims attending emergency department of teaching hospital in central India. Intern Surg J, 3:1618-22.

Rich N.M., and Walker A.J., (2016): The vascular injury legacy. In: Rasmussen IE, Tai NRM, eds. Rich's
Vascular Trauma, 3rd ed. Elsevier Saunders: Philadelphia, PP 1-12.

Taylor D.M., and Cameron P.A., (1998): Deliberate self-inflicted trauma: population demographics, the nature of injury and a comparison with patients who overdose. Aust NZ J public Health, 22:102-5.

Weale R., Kong V., Manchev V., Bekker W., Oosthuizen G., et al., (2018): Management of intraabdominal vascular injury in trauma laparotomy: a South African experience. J Can Chir, 61:185-64.

William D., Robbi A., Jeffery H.,Callie M., and Jacob E. (2015): Use of Pearson's Chi-square for Testing Equality of Percentile profiles Across Multiple Populations. Open J Stat, 5(5):412-420.

Ziffra J.B., Tran P., Strattan M. and Cookman B., (2018): Saphenous vein graft aneurysm and fistula with compression mimicking mitral stenosi s. BMJ, Case Rep 1-5. 


\section{الملخص العربيى}

\section{الجوانب الطبية الثرعية والسريرية لإصابات الأوعية الدموية الطرفية: دراسة استرجاعيه}

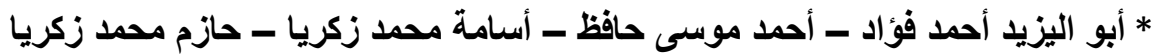

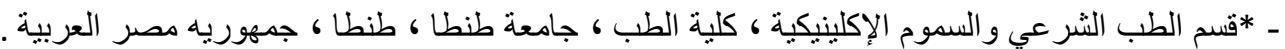

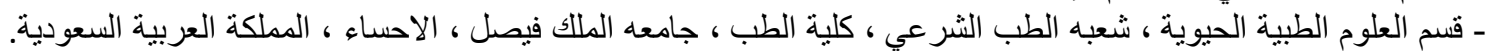

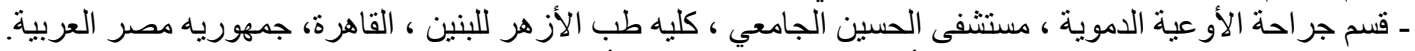
ـ قسم الجر احة العامة ، شعبتي جراحه الأوعية الدموية وجراحه الأطفال ، كلية الطب ، جامعه الملك فيصل ، الاحساء ، المملكة العربية

ـ ـ قسم الجر احة العامة ، شعبه جر احه الأطفال ، كلية الطب ، جامعه قناة السويس ، الإسماعيلية ، جمهوريه مصر العربية. ـ قسم الجراحة العامة ، مستشفى الملك فهد الجامعي ، جامعه الامام عبد الرحمن بن فيصل ، الدمام، المملكة العربية السعودية.

تعتبر إصابات الأو عية الدموية إحدى أنواع الإصـابات المدمرة سواءً كانت عرضية أو متعدده و على الرغم من ذلك، هنالك

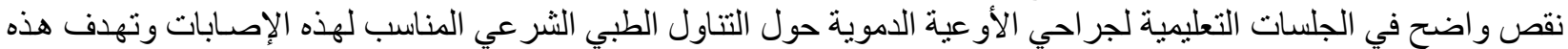

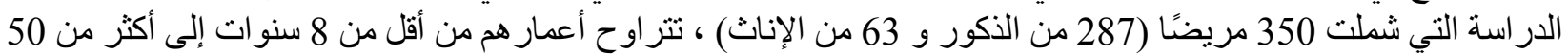

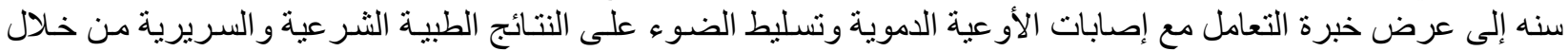

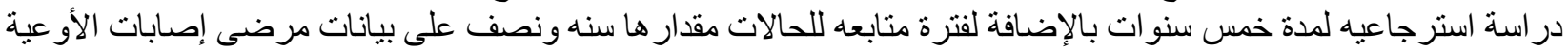

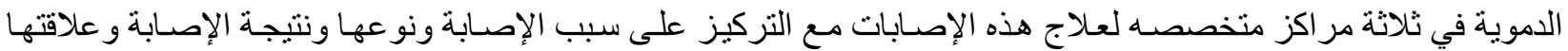

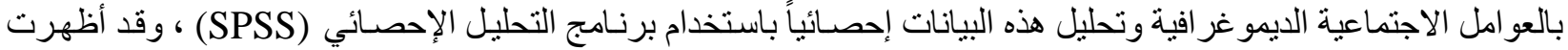

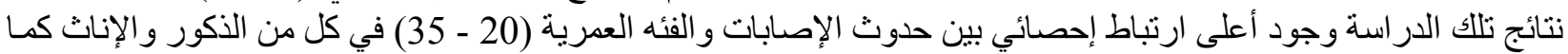

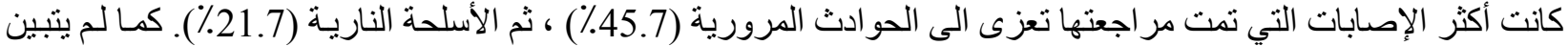

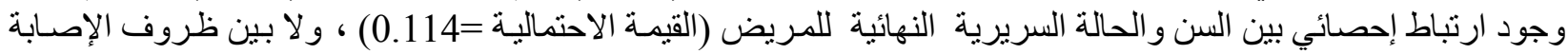

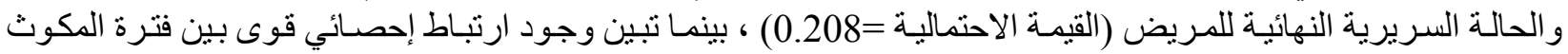

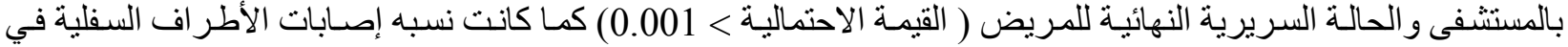

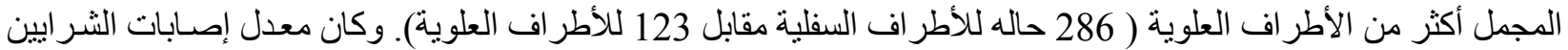

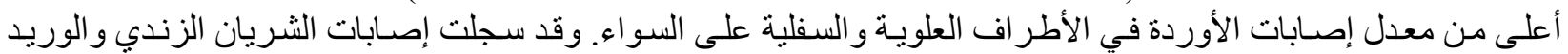

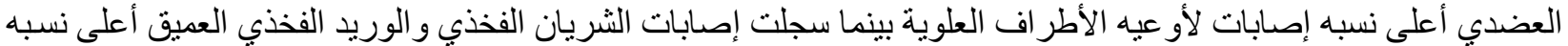

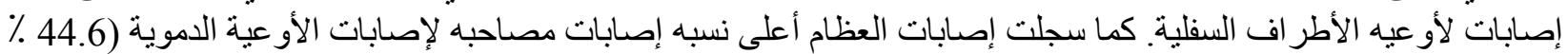

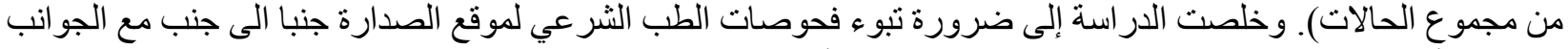
السريرية أثناء التعامل الطبي مع حالات الإصابات بمختلف أنو اعها. 